\title{
DOKUMENTA
}

GORAN ANTONIĆ, istraživač-saradnik

Institut za savremenu istoriju

Beograd, Trg Nikole Pašića 11

\section{REGULACIONI PLAN ZEMUNA ZA PODRUČJE LEVE OBALE SAVE IZ 1932. GODINE}

Prvi poznati planovi za izgradnju urbane strukture na prostoru leve obale Save, gde se nalazi savremeni Novi Beograd, nastali su u doba međuratne Jugoslavije. Iako o toj temi već dugo postoje određena saznanja, ona je u suštini doskora bila istraživački zapostavljena. U periodu socijalizma za nju nije postojalo veće naučno interesovanje, na šta su prvenstveno uticali ideološki faktori. Za tadašnji režim bilo je značajno da istorija urbanog razvoja prostora leve obale Save bude poistovećena sa izgradnjom Novog Beograda kako se ovo graditeljsko delo socijalističke epohe ne bi dovodilo u vezu sa građanskim nasleđem prethodnog vremena. Tek u poslednjih nekoliko godina pojavljuju se stručni tekstovi ${ }^{1} \mathrm{u}$ kojima se ovo pitanje podrobnije obrađuje i ovaj rad predstavlja prilog toj vrsti literature.

U njemu će biti predstavljena dva dokumenta koja su nastala 1932. za potrebe zemunske opštinske uprave. Prvi je „Regulacioni plan grada Zemuna - dela od zemunske železničke stanice ${ }^{2}$ do reke Save sa izmenom odobrene regulacije 1930 g. ", ${ }^{3}$ a drugi je tekst obrazloženja nacrta plana. ${ }^{4}$ Njihov autor je poznati međuratni urbanista i arhitekta Đorđe Kovaljevski. ${ }^{5}$

${ }^{1}$ Videti: Ljiljana Blagojević, Novi Beograd: osporeni modernizam, Beograd 2007; Ranka Gašić, Planovi za izgradnju Beograda na levoj obali Save u međuratnom periodu, Prostorno planiranje u jugoistočnoj Evropi (do Drugog svetskog rata), Beograd 2011, 379-395.

${ }^{2}$ Nekadašnja zemunska železnička stanica koja se nalazila kod današnjeg hotela „Jugoslavija“. Izgradile su je austro-ugarske vlasti 80-ih godina XIX veka.

${ }^{3}$ Istorijski arhiv Beograda (dalje: IAB), fond Skupština opština Zemun (dalje: SO Zemun), inventarni broj (dalje: inv. br.) 256, fascikla (dalje: fasc.) 574, Regulacioni plan grada Zemuna - dela od zemunske železničke stanice do reke Save sa izmenom odobrene regulacije $1930 \mathrm{~g} . .$.

${ }^{4}$ IAB, SO Zemun, inv. br. 275, fasc. 620, Tekst obrazloženja nacrta regulacionog plana upućen Gradskom načelstvu grada Zemuna pod nazivom „Gradskom načelstvu grada Zemuna", s.a.

${ }_{5}^{5}$ Đorđe Kovaljevski je rođen 1888. u Jelisavetgradu u Rusiji (danas Kirovgrad u Ukrajini). Završio je Tehnički fakultet u Kijevu, u kom je kasnije radio kao šef službe za regulacioni plan grada i kao profesor na Politehničkom institutu. Rusiju je napustio posle Ok- 
Dokumenti potiču iz Istorijskog arhiva Beograda i dosad nisu korišćeni u literaturi. Njihov značaj se ogleda u tome što pokazuju da su u periodu između dva svetska rata vlasti u Zemunu bile zainteresovane za širenje lokalne gradske strukture na prostor leve obale Save, što ranije nije bilo poznato kroz stručne tekstove. ${ }^{6} \mathrm{U}$ njima je, inače, pitanje urbanog razvoja ovog područja razmatrano isključivo sa aspekta ekspanzije Beograda.

Nastanak Regulacionog plana bio je uslovljen izgradnjom mosta kralja Aleksandra i puta Beograd-Zemun. ${ }^{7}$ Ideja o izradi saobraćajnih komunikacija s kojima bi se Beograd, preko Save i njene leve obale, povezao sa susednim Zemunom postojala je od osnivanja jugoslovenske države. Njen širi smisao bio je stvaranje preduslova da se Beograd, kao prestonica, teritorijalno proširi do Zemuna, u skladu sa međuratnim planovima o formiranju tzv. „Velikog Beograda“. ${ }^{8}$ Građevinska realizacija, međutim, bila je izuzetno skupa i njen početak se prolongirao do 1930. kada su, uz glavnu finansijsku potporu države, konačno izvedeni prvi radovi na novom mostu i putu. Mada je ovaj graditeljski poduhvat trebalo da omogući budući razvoj prestonice, $\mathrm{u}$ Zemunu se pojavila ideja kako da se on iskoristi za lokalne potrebe. Kao administrativno nadležna za deo područja na levoj obali Save, ${ }^{9}$ zemunska uprava je odlučila da to zemljište planski reguliše i uredi, kako bi ga, po završetku započetih saobraćajnih objekata, prodavala u vidu građevinskih parcela. Očekivalo se da će njihova cena biti visoka zbog male udaljenosti od centra Beograda, a predviđeno je da se sredstvima obezbeđenim na taj način finansiraju projekti značajni za grad. ${ }^{10}$

Za pitanja regulacije angažovan je ugledni stručnjak Đorđe Kovaljevski. Još tokom svog učešća u izradi Generalnog urbanističkog plana

tobarske revolucije i u Beograd je došao 1920. Bio je zaposlen u beogradskoj opštinskoj upravi do 1944, gde je rukovodio sektorom za urbanističko planiranje. Prvenstveno je poznat po učešću u izradi Generalnog urbanističkog plana Beograda iz 1923, uz koji je napravio jedan od prvih planova za širenje Beograda na levu obalu Save. Kao arhitekta projektovao je više značajnih objekata, a među najpoznatijima je zgrada studentskog doma „Kralj Aleksandar I" u Beogradu. - Videti: Marina Đurđević, Urbanističko-arhitektonska delatnost Đorđa Pavloviča Kovaljevskog u Srbiji, Godišnjak grada Beograda, br. XLIX - L, 2002-2003, 169-181.

${ }^{6}$ Značajno je pomenuti da pojedini stručni radovi sadrže podatke koji se indirektno odnose na regulacioni plan Zemuna za prostor leve obale Save. - Videti: Ranka Gašić, Planovi za izgradnju Beograda na levoj obali Save u međuratnom periodu, Prostorno planiranje u jugoistočnoj Evropi (do Drugog svetskog rata), 386; Marina Đurđević, Urbanističko-arhitektonska delatnost Đorđa Pavloviča Kovaljevskog u Srbiji, Godišnjak grada Beograda, br. XLIX - L, 2002-2003, 172.

${ }^{7}$ Podvodno zemljište preko puta Savskog pristaništa pretstavljaće jedan od najuređenijih krajeva budućeg velikog Beograda, Vreme, 24. mart 1932.

8 "Veliki Beograd“ je trebalo da obuhvati Zemun i Pančevo.

${ }^{9}$ Drugi, veći deo je bio u posedu bežanijske opštine.

${ }^{10}$ IAB, SO Zemun, inv. br. 268, fasc. 611, Zapisnik VIII redovne skupštine zastupstva grada Zemuna, 10. septembar 1931. 
Beograda iz 1923, on je samoinicijativno napravio jedan projekat za proširenje prestonice na prostor leve obale Save, ${ }^{11}$ zbog čega je već bio upoznat sa problemima uređenja ovog područja. Takođe, kao dugogodišnji rukovodilac odseka za urbanistička pitanja u beogradskoj opštini mogao je da usaglasi zemunski regulacioni plan sa potrebama razvoja Beograda, o čemu se u upravi Zemuna vodilo računa, zbog njegovog odobrenja od strane nadležnih državnih ustanova. U februaru 1931. Kovaljevski je napravio skicu regulacije, na osnovu koje je definisan preliminaran program za izradu plana. Njime je bilo predviđeno uređenje celog prostora leve obale Save a ne samo zemunske teritorije, kako je prvobitno zamišljeno. ${ }^{12} \mathrm{Na}$ zahtev zemunskih vlasti, tokom 1931. sastavljena je mešovita stručna komisija od predstavnika državnih ministarstava ${ }^{13}$ i gradske opštine Zemun, koja je program proučila i donela zaključke u vezi s njim. Na osnovu toga, Kovaljevski je do marta 1932. napravio nacrt regulacionog plana, koji je početkom jula potvrđen u zemunskoj gradskoj skupštini. ${ }^{14} \mathrm{U}$ julu naredne godine plan je dobio odobrenje Ministarstva građevina, ali samo za područje između železničke pruge Beograd-Zemun i obala Save i Dunava. ${ }^{15}$ To je, kao konačnu odluku, trebalo da potvrdi vlada, međutim, beogradska uprava je marta 1934. uključila Zemun u sastav prestonice, što je obustavilo njegovo usvajanje i dalju realizaciju. Tokom 1935. beogradske vlasti su jedno vreme razmišljale da ga iskoriste za svoje potrebe, ${ }^{16}$ ali se od toga kasnije odustalo.

Idejnim konceptom plana bilo je predviđeno da buduće gradsko naselje na teritoriji leve obale Save bude istovremeno novi deo i Zemuna i Beograda, kao mesto njihovog međusobnog spajanja. Ono bi bilo podeljeno na tri zone, diferencirane po gustini naseljenosti - područje guste, srednje i retke naseljenosti. ${ }^{17}$ Područje guste naseljenosti trebalo je da bude administrativno, poslovno i kulturno jezgro naselja. U središtu ovog područja bi se nalazio centralni trg, koji bi mrežom radijalno postavljenih saobraćajnica

${ }^{11}$ Ljiljana Blagojević, Novi Beograd: osporeni modernizam, Beograd 2007, 24.

12 IAB, SO Zemun, inv. br. 239, fasc. 554/II, Zapisnik nastavljene II redovne skupštine zastupstva grada Zemuna, 20. februar 1931.

${ }^{13} \mathrm{U}$ radu komisije učestvovali su predstavnici Ministarstva građevina, Ministarstva saobraćaja i Ministarstva socijalne politike i narodnog zdravlja.

${ }^{14}$ IAB, SO Zemun, inv. br. 283, fasc. 636, Zapisnik VIII redovne skupštine zastupstva grada Zemuna, 5. jul 1932.

${ }^{15}$ Ministar građevina je odobrio regulacioni plan inundacionog terena, Vreme, 23. jul 1933.

${ }^{16}$ IAB, SO Zemun, inv. br. 256, fasc. 574, Dopis Gradskog veća upućen Tehničkoj direkciji, 28. maj 1935.

17 1) područje guste naseljenosti - između Save, Dunava i železničkog nasipa; 2) područje srednje naseljenosti - između industrijskog dela Zemuna (u okolini zemunske železničke stanice), železničkog nasipa, aerodroma i reke Save 3) područje retke naseljenosti ostali deo terena. 
bio povezan sa ostalim delovima naselja, kao i sa Beogradom, Zemunom i Bežanijom. U centru trga bi se nalazio monumentalan spomenik, dok bi oko njega bile podignute javne građevine. Pored ovog, na područjima guste i srednje naseljenosti bi se izgradilo još manjih trgova i na tim mestima bi, takođe, bili podignuti spomenici i javne građevine (crkve, gimnazije, muzeji i dr.). Na prostoru čitavog naselja bi se ravnomerno rasporedila brojna dečija igrališta, a ono bi imalo i prostrane komplekse zelenih površina. Postojeći aerodrom kod Bežanije ${ }^{18}$ ostao bi na istoj lokaciji, kao i zemunska železnička stanica koja bi se proširila za potrebe lokalnog stanovništva. Naselje bi dobilo i svoje pristanište, koje bi se sagradilo u rukavcu između dunavskog ostrva Vrbak ${ }^{19}$ i kopna. Ostrvo bi se spojilo sa obalom na zapadnom kraju i na njemu bi se podigli magacini, koji bi železničkim kolosecima bili povezani sa železničkom stanicom. Kod pristaništa bi se nalazila glavna pijaca, oko koje bi se formirao privredni centar naselja. Naposletku, uz most kralja Aleksandra bi se podigao i most na Adi Ciganliji, koji bi omogućio vezu ne samo sa Beogradom, već i sa šumadijskim regionom. ${ }^{20}$

Iz ugla kritike izvora značajno je istaći da je na Regulacionom planu učinjena jedna naknadna intervencija od strane nepoznatog autora. Reč je o saobraćajnici pravolinijske putanje, ucrtanoj isprekidanim linijama na severnom delu plana. Gotovo sigurno je u pitanju projekcija puta aerodromBeograd, koji je sagrađen 1938. Pored trase ${ }^{21}$ na to ukazuje i činjenica da je tokom 1935. beogradska uprava nameravala da plan Kovaljevskog upotrebi za uređenje leve obale Save, s tim da se on uskladi, između ostalog, i sa maršutom puta za aerodrom, koji je tada bio u fazi planiranja. ${ }^{22}$

U vezi sa tekstom obrazloženja nacrta plana treba pomenuti da on ne sadrži naslov, datum nastanka i ime autora. Analizom njegovog sadržaja može se utvrditi da ga je sastavio Đorđe Kovaljevski. Najverovatnije je

${ }^{18}$ Nekadašnji aerodrom „Beograd“ koji se nalazio između Bežanije i Zemuna. Izgrađen je 1927. kao prvi beogradski aerodrom.

${ }^{19}$ Ada Vrbak (Vrbljak) se nalazila južno od Malog ratnog ostrva. Spojena je s kopnom 1938, zatrpavanjem uskog rukavca koji je ostrvo razdvajao od obale. Radove je obavio konzorcijum „Danska grupa“, koji je od maja 1938. nasipao zemljište na prostoru leve obale Save za beogradsku opštinu.

${ }^{20}$ IAB, SO Zemun, inv. br. 275, fasc. 620, Tekst obrazloženja nacrta regulacionog plana upućen Gradskom načelstvu grada Zemuna pod nazivom „Gradskom načelstvu grada Zemuna", s.a.; Podvodno zemljište preko puta Savskog pristaništa pretstavljaće jedan od najuređenijih krajeva budućeg velikog Beograda, Vreme, 24. mart 1932; Ministar građevina je odobrio regulacioni plan inundacionog terena, Vreme, 23. jul 1933.

${ }^{21}$ Ucrtana saobraćajnica pravolinijski spaja nekadašnju ulicu Venecija i put Beograd-Zemun, kako je to činio put za aerodrom.

${ }^{22}$ Ispravku je zahtevalo Ministarstvo građevina radi odobrenja plana; videti: IAB, SO Zemun, inv. br. 256, fasc. 574, Dopis Ministarstva građevina upućen Poglavarstvu grada Beograda (Tehnička direkcija), 26. jun 1935. 
nastao u martu 1932, kao prilog nacrtu regulacionog plana koji je tada dostavljen na uvid zemunskoj upravi. Napisan je na pisaćoj mašini i na njemu $\mathrm{su}$, takođe, vršene kasnije intervencije u vidu rukom pisanih ispravki koje su delo nepoznatog autor. Uz pravopisne korekcije, u njih spadaju sitne prepravke i dopune teksta koje bitno ne menjaju njegov smisao. U skladu s tim, one u priređenoj verziji dokumenta koja se pojavljuje u ovom radu nisu unesene, sem u jednom važnijem slučaju.

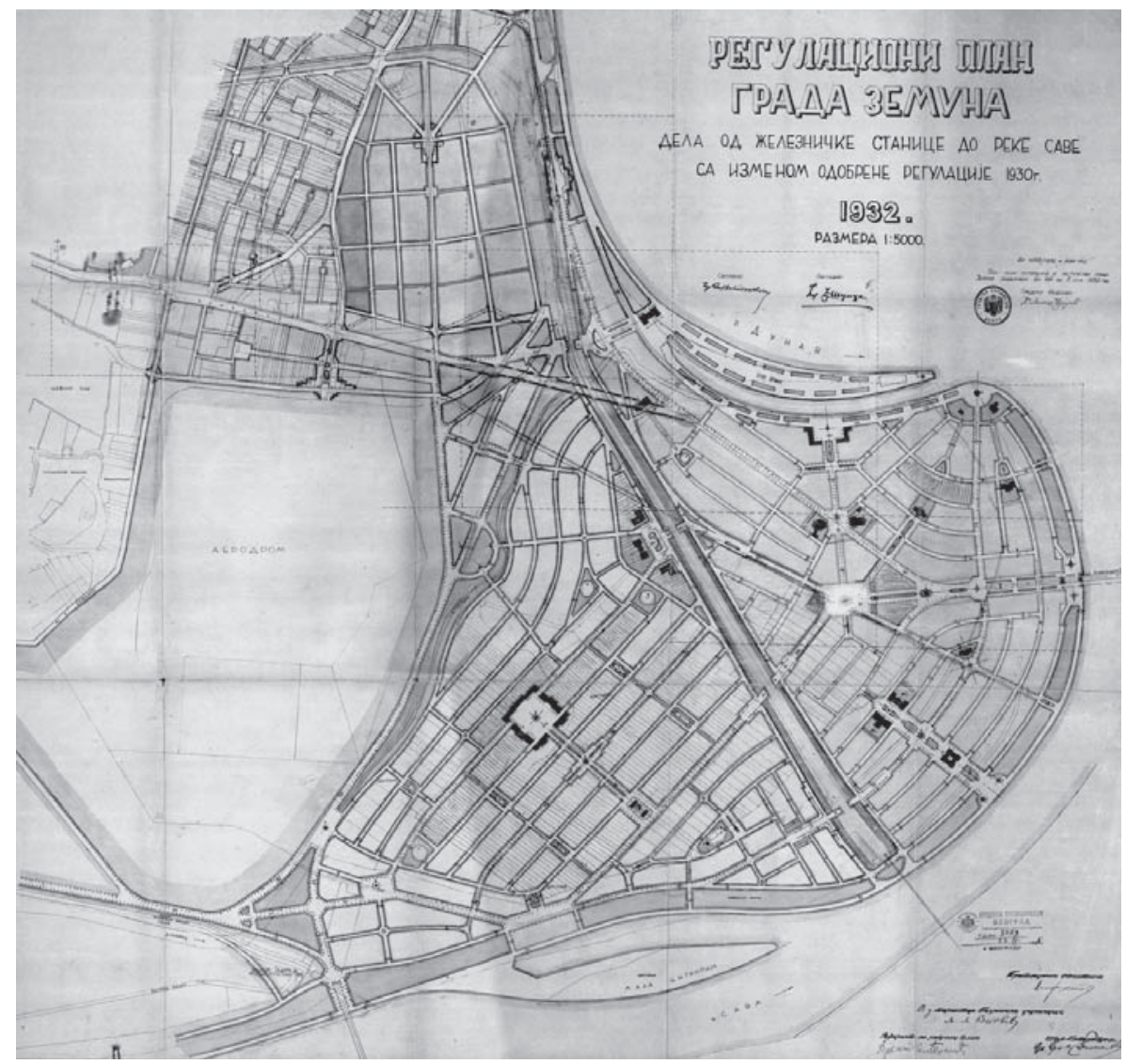




\section{GRADSKOM NAČELSTVU GRADA ZEMUNA}

\section{Uvod}

Prema ugovoru sklopljenom sa gradskom opštinom ${ }^{23}$ bila mi [je $]^{24}$ dužnost da izradim generalni regulacioni plan u razm. 1:25000, područja koje se proteže između Dunava, Save i Bežanijske kose i granice zemunskog i bežanijskog hatara t.j u razm. 1:5000 onog dela područja, koje se prostire između Dunava, Save i željezničkog nasipa ${ }^{25}$ (inundacioni teren u užem smislu).

Da bi što jasnije prikazao generalni projekat izradio sam plan u razm. 1:5000 za celo područje, koje se napred opominje, ${ }^{26}$ a za podlogu su mi služile katastarske mape Zemuna i Bežanije, kao i rekogniociranje terena.

\section{Tehnički opis}

Iz plana se vidi, da sam postupio prema zaključcima konferencije stručnjaka, ${ }^{27}$ te sam ceo kompleks razdelio u tri vrste naselja (gusto, srednje i retko) a osim toga sam ostavio velike površine (kao zaštitni pojasevi) za nasade i eventualno proširenje naselja.

Kod rešavanja ovog problema uzeti su u obzir osim inundacionog terena čija je izgradnja na dnevnom redu i cela okolina napred opomenuta, da bi se omogućila u budućnosti što bolja veza prometnih potezova, dok je samo rešenje s čisto urbanističke strane šematski, jer izgradnja toga dela zemljišta za sada ne dolazi u obzir.

Iz tih razloga ću u ovom izveštaju i govoriti samo o regulaciji inundacionog terena.

Inundacioni teren zauzima ravnicu između Dunava, Save i željezničkog nasipa na prosečnoj koti 71.50 i manji deo bliže obali - 73.0 a ostalo oko 71.0. Na granici tog terena je željeznička pruga Zemun-Beograd sa nasipom na koti oko 76.0 i sa prostranim materijalnim rovovima u širini

${ }^{23}$ Gradska opština Zemun.

${ }^{24} \mathrm{U}$ uglaste zagrade u tekstu unesene su dopune priređivača.

${ }^{25}$ Železnički nasip koji je štitio nekadašnju prugu Beograd-Zemun. Prugu su izgradile austrougarske vlasti 80-ih godina XIX veka, u skladu sa odredbama Železničke konvencije sklopljene 1880. sa Kneževinom Srbijom. Ona je, inače, bila prvi stalni saobraćajni objekat na tlu današnjeg Novog Beograda.

${ }^{26}$ Odnosi se na područje koje trebalo izraditi u razmeri $1: 25000$.

${ }^{27}$ Mešovita stručna komisiji formirana 1931. sa zadatkom da prouči zemunski predlog regulacije inundacionog terena i da donese zaključke vezi s njim. 
80-120 metara. Približno sredinom toga terena izrađuje se pristupni put ${ }^{28}$ od novog mosta Kralja Aleksandra do želj. stanice Zemun, ${ }^{29}$ koji se spušta prema sadanjem projektu po nasipu visine 17 metara, padom na $2 \%$ na tle. Celo zemljište u površini od cca 245 ha je većinom oko $2 / 3$ svojina Zemunske opštine a 1/3 zemljišne zajednice Bežanijske opštine i privatnih sopstvenika.

Radeći na ovom problemu držao sam se zaključka konferencije stručnjaka, koji su prošle godine jednoglasno utvrđeni: da se sadanji teren podigne do kote iznad visoke vode t.j. na približnu kotu 75.60-76.00, da inundacioni teren bude upotrebljen za gusto trgovačko naselje sa pristaništem, i da se kompleks reši u glavnom kao što je izvedeno u skici regulacije ${ }^{30}$ koju sam izradio prošle godine u razm. 1:15.000.

Pomenuta skica je poslužila za bazu novog nacrta rađenog na osnovu raspoloživih katastarskih mapa.

Prilikom izrade regulacionog plana uzeti [su] u obzir postojeći faktori i objekti kao i buduće potrebe novog dela Zemuna odnosno Beograda u pogledu saobraćaja, higijene, estetike i što ekonomičnijeg iskorišćenja toga zemljišta. Postojeći važni putevi i veze sa Zemunom i Beogradom sačuvane su ili prilagođene novom planu sa neznatnim korekcijama. Vođeno je računa o postojećim kanalima, granicama etc. kako bi plan bio što realniji.

\section{$\underline{\text { Raspodela naselja }}$}

Sačuvan je isti raspored kao i u skici 1931. god.: 1) Gusto naselje zauzima prostor između 2 reke i želj. nasipa pruge Zemun-Beograd. 2) Naselje srednje gustine - prostor između želj. nasipa, aerodroma, ${ }^{31}$ r. Save i industrijskog dela ${ }^{32}$ postojećeg Zemuna. 3) Ostali teren namenjen je za retko naselje. Razume se u svakom od pomenutih naselja treba umetnuti i blokove sa naseljem druge vrste: napr., u zoni gustog naselja treba predvideti $u$ sporednim ulicama blokove sa naseljem srednje gustine, a u naselju srednje gustine $-\mathrm{u}$ njegovom administrativnom centru i trgovačkom delu - gusto naselje. Isto važi i za retko naselje.

\footnotetext{
${ }^{28}$ Put Beograd-Zemun.

${ }^{29}$ Nekadašnja zemunska železnička stanica koja se nalazila kod današnjeg hotela „Jugoslavija".

${ }^{30}$ Skica regulacije koju je Kovaljevski izradio za zemunsku upravu februara 1931.

${ }^{31}$ Nekadašnji aerodrom „Beograd" kod Bežanije.

${ }^{32}$ Industrijska zona grada u okolini nekadašnje zemunske železničke stanice.
} 


\section{Saobraćaj}

a) Ulice

Glavna saobraćajnica je pristupni put ka mostu Kralja Aleksandra, koji se proširuje od sadanjih $18.0 \mathrm{~m}$ na $30 \mathrm{~m}$. dok se trasa podudara u glavnom sa postojećom sa tom razlikom, što se proširenje toga puta pred željezničkom stanicom Zemun $\mathrm{u}$ trg ${ }^{33} \mathrm{u}$ interesu lokalnog i tranzitnog saobraćaja znatno proširuje.

Od drugih važnih saobraćajnica pominjem: 1) veza gore pomenutog pristupnog puta sa kružnom saobraćajnicom oko Zemuna, koja je predviđena već regulacionim planom grada Zemuna 1930. god, sa jednim podvožnjakom koji je vezan sa putem kružnim rampama; 2) veza između sela Bežanije i okoline sa centrom budućeg naselja (30 met. širine); 3) veza glavnog trga naselja ${ }^{34}$ sa centrom pristaništa (25.0 met. širine); 4) veza sela Bežanija sa mostom Kralja Aleksandra i dalje sa pristaništem. Za pravac ove veze je postojeći obranbeni nasip ${ }^{35}$ koji ide paralelno sa r. Savom; 5) ulica na granici atara Bežanijskog i zemunskog i 6) ulica koja pored aerodroma veže centar Zemuna i kružnu Zemunsku saobraćajnicu sa Čukaricom, Topčiderom, Topolom, Kragujevcom itd., sa 2 mosta preko Save (Ada Ciganlija).

Najmanja širina ulice, ne računajući pasaže od $5.0 \mathrm{~m}$. širine je 15.0 metara. Sporedne saobraćajnice uzete su širine od 18 do 22 met. kako je to primljeno i u regulacionom delu ${ }^{36}$ Zemuna iz god. 1930.

b) Željeznica

Sadanja željeznička stanica ostaje na istom mestu samo se predviđaju proširenja i veze sa budućim pristaništem, koje treba da se formira između otoka Vrbaka i obale.

\section{c) Pristanište}

Spajanje otoka sa obalom dobija se pristanište dovoljnog kapaciteta da zadovolji samo potrebe novog naselja, jer po regulacionom planu Beograda za Beograd je predviđeno pristanište na Dunavu. U planu su šematski ucrtani magazini i koloseci.

${ }^{33} \mathrm{U}$ originalnom dokumentu deo rečenice „u trg“ naknadno je precrtan rukom. Verovatno je reč o izmeni prvobitnog plana koji je predviđao izgradnju trga kod železničke stanice.

${ }^{34}$ Centralni trg u zoni gustog naselja.

${ }^{35}$ Deo Savskog nasipa koji je 1908. izgradila „Zadruga za isušenje jugoistočnog Srema“ na potezu između Boljevaca i Bežanije. U njegov sastav je 1909. uključen i stari Bežanijski nasip koji su na tlu savremenog Novog Beograda sagradili Austrijanci još krajem XVIII veka.

${ }^{36}$ Misli se na regulacioni plan Zemuna iz 1930. 
Blokovi

Kod rešavanja blokova u pogledu veličine i rasporeda primljeni su ovi principi moderne tehnike uređenja varoši. Ogromni kompleksi opštinskog zemljišta dali su mogućnost primene racionalnih rešenja u pogledu dimenzija blokova ali je vođeno takođe računa i o privatnim zemljištima, izbegavajući bez naročite nužde poslove oko komasacije i eksproprijacije zemljišta. Regulacija, napr. srednjeg naselja rešena je baš u smislu što lakšeg njenog izvođenja, vodeći računa o granicama opštinskog i privatnih imanja. Pada u oči da su blokovi u interesu što racionalnijeg iskorišćenja zemljišta uzani i dugački, a osim toga raspoređeni, da je orjentacija u naselju veoma olakšana. O položaju vetra i o stranama sveta vođeno je računa samo u toliko u koliko ne bi bilo na štetu racionalnog iskorišćenja zemljišta.

\section{Nasadi i zaštitni pojas}

Parkovi i druge slobodne površine ovoga dela Zemuna nalaze se $u$ srećnom položaju. Opkoljen sa severa, istoka i juga rekama, koji će stanovništvu pružiti stalan priticaj svežeg vazduha, ovaj kraj će imati duž istočne i južne obale pojas parkova kao i uzduž željezničkog nasipa. Najzad su svi delovi grada ravnomerno snabdeveni skverovima i dečijim igralištima.

\section{Građevine}

Položaj javnih građevina, koji je samo šematski rešen, i njihova namena vidi se iz plana. Najmarkantnija tačka u varoši će biti centralni trg, sa kojeg zrakasto idu na sve strane saobraćajnice i gde će se koncentrisati lokalni administrativni i kulturni centar. Privredni centar sa glavnom pijacom predviđa se na pristaništu.

\section{Zaključak}

Pristupni put ka mostu Kralja Aleksandra ušao je u mrežu varoških ulica kao glavna saobraćajnica samo je nemoguće ostaviti njegovu niveletu onakvu, kakva je ona projektovana, jer sa svojim padom od $2 \%$ razdelio je celu pomenutu teritoriju na dva dela, te je veza ovih delova sa mostom Kralja Aleksandra i Beogradom otežana, što se zbog budućeg razvitka grada ne bi smela dopustiti. Zato je potrebna korekcija puta kako je to predviđeno 
regulacionim planom: 1) povećati pad sa $2 \%$ na 4\% i 2) zamenuti nasip 17 $\mathrm{m}$ visine vijaduktom, koji bi se mogao iskoristiti.

$\mathrm{Na}$ osnovu toga trebala bi gradska skupština nastojati, da se predložena izmena odmah i provede, jer će u protivnom pitanje izgradnje ovog terena biti u budućnosti veoma otežana i skopčano sa ogromnim žrtvama. 